DOI https://doi.org/10.18551/rjoas.2017-05.30

\title{
THE CASE OF RELATIONSHIP BETWEEN REWARDS AND KNOWLEDGE-SHARING WITH MULTIPLE CULTURE AS MODERATORS
}

\author{
Jabid Abdullah W.* \\ University of Khairun, Ternate, Indonesia \\ Doctoral Degree Program in Management, University of Brawijaya, Indonesia \\ Moeljadi, Indrawati Nur Khusniyah, Sumiati \\ Faculty of Economics and Business, University of Brawijaya, Indonesia \\ *E-mail: abdullah.wajir@yahoo.com
}

\begin{abstract}
Several studies have explored the relationship between rewards and knowledge-sharing in private and public settings with mixed results. The same case also holds to the relationship between culture and knowledge-sharing. The present paper attempt to seek way out from this dead-end situation by looking people not as individuals who are necessarily being motivated when offered rewards in order to have willingness and intention to share their resources to others but instead as individuals in a continuous subjugating and dominating dynamic process with his/her environment in which culture is a part. He/she can make a step further of dominating or making new culture conceived suitable to make organization he/she manages adaptive and competitive comparative to others. The paper sheds lights on different advance in knowledge-sharing development at public institutions by synthesizing social exchange and structuration theories.
\end{abstract}

\section{KEY WORDS}

Rewards, culture, knowledge-sharing, social exchange, structuration.

In the highly dynamic business environment, organizations must adapt quickly in response to the changing needs of their stakeholders. To handle those overwhelming needs, many organizations hugely invest in knowledge management. Knowledge management (KM) is the process of creating, sharing, using and managing the knowledge and information of an organization (Girard, et al, 2015). It refers to the process of gathering and spotting useful information, transferring it (knowledge transfer or creation), compiling and depositing it (organizational memory), spreading it through the whole organization (knowledge sharing), enabling employees to recall (knowledge retrieval) and exploiting and usefully applying knowledge (knowledge leverage) and making use of it optimally (Demigha, 2015). One of the main activities of KM is "knowledge sharing" from which, organizational member can contribute to knowledge application, innovation, and performance of the organization (Ammar, et al., 2014). It is only possible if there is willingness and intention to share knowledge among all stakeholders involved, particularly skilled staff and leaders.

Even so,most of the studies cite motivation and culture as main drivers of knowledge sharing. Heydari et al., (2011) holds that reward should be put into motivation design for knowledge-sharing to materialize. If finds support from early works such as Osterloh \& Frey, (2000) and Bartol dan Locke, (2000) for monetary rewards and Davenport \& Prusak, (1998), Hargadon, (1998), Akhan and Rahimi, (2013), and Marti'n-Pe'rez et al., (2012) for nonmonetary rewards.

Researches of the relationship between rewards and knowledge-sharing have been mixed. Allameh et al., (2012), for instance, has found that rewards has effect on staff attitude and intention to share knowledge. It is in line withthe studies of Wickramasinghe \& Widyaratne, (2012); Witherspoon et al., (2013); Kim \& Lee, (2006); and Kang et al., (2008); Al-Alawi et al., (2007); Marti'n-Pe'rez et al., (2012); and Durmusoglu et al., (2014); Lim et al., 
(2004), and Akhan \& Rahimi (2013) all of which confirm the capability of reward as a motivation main driver leading to sharing-knowledge attitude.

Others show otherwise. Amayah' study (2013), for instance sets a ground for relation absence between rewards and knowledge-sharing in public sector. The research results of Tohidiniaand Mosakhani, (2010); Kumar \& Rose, (2012); Wu \& Zhu, (2012); Bock et al., (2005); Lin, (2007) and Bock \& Kim, (2002) have the same vein.

As of culture, a recent body of literature has shed light on the role played by organization's culture as one of the best strategies to enhance knowledge management via knowledge sharing. Organizational culture is defined as a set of implied hypotheses accepted by group members that determines the way of behaving and responding to their surroundings. The culture has multiple levels ranging from a visible to an implied and invisible one (Schein, 2004).

Culture is both a key driver and inhibitor of organizational knowledge sharing (O'Dell, \& Grayson, 1998. According to Delong \& Fahey (2000), there are four reasons why culture is the base of knowledge sharing: culture shapes assumptions about what knowledge is important, culture determines what knowledge belongs to the organization or to the individual, it creates a context for social interaction about knowledge and culture shapes the creation and adoption of new knowledge. In the same direction, Cabrera \& Cabrera (2005) suggest that organizational culture influences knowledge sharing in two ways: first, by creating an environment in which there are strong norms regarding the importance of doing this behavior, and second, creating an environment of caring and trust. Besides that, several studies identified "cultural barriers" as one of the key factors influencing the successful implementation of knowledge sharing activities in a firm (Rivera-Vazquez et al., 2009).

Studies supporting the formers include Al Murawwi et al., (2014); Suppiah \& Sandhu, (2011); Cavaliere and Lombardi (2015), and Shao et al., (2015), among others. Those supporting the latter are include Kim (2013) and Alrawi et al., (2013).

These contradictory results provide justification base of the present study. It attempts to find ways out for the mixed results for the relationship between rewards and knowledgesharing, and for that between culture and knowledge-sharing, by designing model analyzing the relationship between rewards representing motivation and knowledge-sharing with (multiple) culture as moderators. To do this, it applies the combination social exchange theory and structuration theory to grasp above issues, especially application of the model in public sector context. The study focuses its application in municipal government of Ternate, in Maluku province.

The bulk of KM research has given much focus on private sector organizations, with relatively little part on the public sector (Syed-Ikhsan \& Rowland, 2004). In spite of this however, public landscape is changing as public organizations face increasing pressure to implement reforms and heighten their efficiency and effectiveness (O'Riordan, 2005). There has been effort to apply sector models to the public sector, such as debureaucratisation (Siddiquee, 2010). Given these changing contexts, it is common to find the adoption of management concepts and models applied in private organizations in public sector (Northcott, 2012).

\section{LITERATURE REVIEW}

The social exchange theory. It is proposed by Blau in 1964 and is instrumental to grasp individual's behavior in knowledge-sharing. According to this theory, individuals' interactions are much influenced by consideration of costs and benefits. People seek to maximize expected benefits and minimize anticipated costs when deciding to exchange resources with others (Molm, 2001). In maximizing resources, individuals may make relationships with others by sharing their knowledge. Davenport \& Prusak, (1998) have cited several benefits that may determine people's behavior in knowledge sharing behavior, covering mutuality, status, career chances, and promotion.

Structuration theory. It is put forward by Giddensas an effort to explain intertwined relationship between social structure and human action as an agency. External structure can 
not exist without the existence of action, and vice-versa. Individuals as agents not only reproduce structure, but also have subjective capabilities to produce subjective and objective realities (Giddens, 1984: 49). They not only make structure as medium, but also outcome. Reality of external structure can serve as constraining or even enabling factor to the agent. Action and reaction between structure and actor run continuously, and the process reflects the actor ability or disability, subjugation or domination, and activity and passivity. The relationship is called duality of structure. This theory reflects an effort to make a meeting point between structure and actor.

Pertaining to the issue of culture-knowledge sharing relationship, the theory is conceived as handy in explaining the case where leaders in an organization faced with existing culture working as constraining factor instead of enabling manage to dominate in order to steer organization to achieve intended performance.

\section{METHODS OF RESEARCH}

The paper applies literature and descriptive review. By reviewing some relevant literature and theories implied within, it intends to grasp the phenomenon of reformation in governmental institutions in terms of relationships between rewards and knowledge-sharing with (multiple) culture as moderator-(s) in Indonesia, with municipal government as a starting-point. While most studies of relationships between rewards, knowledge-sharing and culture, puts existing culture as a dominating factor, the present study attempts to view the relationships in a rather different angle, by putting human as an active agent who has ability to adapt culture to suit to organizational objectives. In doing so, the interplay between social exchange theory and structuration theory is imperative.

Public organizations has different traits and objectives from those of private business organizations. The former is oriented to the best service provision to society, while the latter is to profit. Even so, there is a minimal development in methods of delivering the service to the hands of society as reflected in a still widespread complaint among people of its quality and efficiency. The fact that governmental institutions have long experiences in providing and delivering service is not compatible to their capability to making optimal use of their supposedly accumulating learning inventory.

Many studies have confirmed that most of public institutions fall victims to bureaucratic malaise and its related culture. Positive turnaround leading to heightened performance should be accompanied with its bureaucration reformation. James Q Wilson, (1989) emphasizes the significance of actors' ability to manage the room for learning process on place and accessible to all stakeholders. Wilson argues that bureaucracy is commonly highly resistant to innovation in circumstance where staff enjoys much preference, financial support, and overwhelming authority. Bureaucratic institutions lean on stability and routine for all their activities. It might be a inhibiting factor on knowledge management and the pursuit of learning organization.

Bureaucratic organizations are encumbered by growingly increased pressure from public of improved service, limited budget and new information technology requiring immediate support from government. One breakthrough solution to overcome all these issues is bureacration reformation in attempt to pursue heightened innovation and performance. It entails an organization-wide shake-up to governance system, especially by accounting for its structure, administration process, and underlying human resources. Knowledge-based bureaucratic operation becomes the only best option to lay sound ground for bureaucratic reformation. It is more so due to the fact that reformation is designed to bring up some new innovations requiring personnel to have relevant knowledge to handle those innovations.

Ternate is one of the biggest cities in North Maluku province possessing dormant potentials to explore. Its leaders have intended to make Ternate as Cultural, Tourism, trading centre, and economic city. Several determining steps have been taken to materialize these objective. The most strategic measure is internal reformation, including system and administration in municipal government. Because of this measure, the municipal government 
has been awarded by National Office for Staffing (BKN) for its success in nurturing and developing its staff. Among eight categories covering: staffing planning, service for personnel's rank proposal, service for pension matters, CAT (Computer Asset Test for Recruitment) implementation, performance evaluation implementation, assessment centre, e-PUPN (Electronic Registration Of Civil Servants), and innovative BKD (Regional Office For Staffing), municipal government of Ternate is conspicuous in service personnel's rank proposal, being the only regional government in Maluku province have accepted the reward.

Modern government holds on the principle of "bringing the state closer to the people" as a compelling norm. Thus, shake-up carried out by regional government on the behalf of organization restructuration should have a significant effect on the increased public policy quality. Governmental reorganization should be carried out in a such way that leads to good governance, in terms of accountability, transparence, participation, responsiveness, effectiveness and efficiency. The current trend unveils the fact that most of regional governments in Indonesia still can only achieve managerial reformation at minimally mediocre degree.

One good example is Ternate city. It has so far managed itself as the city of service, trade, culture, tourism and economy. One of the significant measures is to make available communication between government, and its stakeholders including people, businessmen, tourists and others and updated information accessible online to the latters. It can only be materialized by knowledge management of which sharing knowledge is a part. Other measure related to knowledge management is an attempt to develop Ternate as a Smart city within which the framework is put in place enabling online two-directions communication between government and its public important to grasp the emerging issues. The Smart city is also intended to make much more efficient and effective service delivery free of time and space barrier.

A study by a research team of STIA LAN Makassar, (2012) concerning competencies of regional governments' personnel in Indonesia compares 6 regional government including Sorong regency, Bandung city, Mamuju regency, Kendari city, Kupang city, and Ternate city and brings up several findings relating to knowledge management. Among those six regional governments, Ternate gets the highest rank with fair grade in points of delivering and clarifying state-of-art knowledge in the position as experts, helping other people having technical problems, spreading new technology outside organization, publishing paper of new method at professional journals.

Ternate gets the highest rank with fair grade in points of having awareness of new technology, actively developing technology in place and developing curiosity to master new skills and keeping up pace with recent development of a certain knowledge.

Ternate gets the highest rank with fair grade in points of mastering knowledge concerning of the tasks and having technical expertise necessary to contribute or share the knowledge to other people. Ternate gets the second rank after Kupang city in making use of existing culture to uphold the pursuit of organization's goals.

Study of Hamka et al. attempts to measure Ternate city's performance in terms responsibility, transparency, and efficiency reflecting the degree to which the city has gone in knowledge management. The report of the city progress in those three items is also being attempted to be accessible online by public by making available wi-fi infrastructure in several public places though so far only in a limited number. The study puts the city's performance in responsibility item at above average grade, the city's performance in transparency and efficiency at rather lower average grades.

The above analysis unveils that the leaders of Ternate City have not only dismantled overarching bureaucratic culture permeating all sectors in a governmental institution, they also modify and direct it to the attainment of knowledge sharing and best service culture. Knowledge sharing itself is a culture, where sharing what people have on the behalf on organization's objective of delivering services is a norm, is related to service culture. Leaders should direct bureaucratic culture where the perspective that the bureaucrats deserves respect and good services from public is widespread to service culture where the bureaucrats themselves should provide the best services based to knowledge sharing to the 
public. The culture refers to complying to the common value and belief in a society or organization voluntarily as the faith to the value and belief make them to do so, and they accept it as taken for granted. At this point, rewards-based motivation plays much less importantly than that in the previous stage where sharing knowledge practice is still in transactional stage. Changing culture to the rewards-based transitory practice or habit is distinct to that to new culture where the intended practice is voluntary in nature. The former has a ground on social exchange theory, while the latter does on structuration theory. On the latter, individuals are not subject to their environment, instead they play dominant role above the environment and direct to the point of their goals. Leaders in an organization should make a culture-wide change, in that all individuals make new practices voluntarily as they submerge in the new value and system that make the practices as the best option to do.

In the case of municipal government of Ternate, the personnel and leaders are at the point of cross-roads between rewards-based and value-driven practices. Points along the way is a struggle of muddling through to the end of the way, along which there is a force of the remaining old culture to retreat. When they arrive at end point, rewards no longer serves as a driver of motivation to do the intended practices, rather as signs of status and appreciation. Municipal government of Ternate still have difficulty in handling culture as it is the most determining factor of the success of organizational reformation. The idea is that organizational reformation without culture changing is only temporary change in color and shape without the true change of the content.

\section{RESULTS AND DISCUSSION}

Study of regional government under the theme of knowledge sharing for reformation should pay heed to "human-directed culture" in the analysis of cultural effect as moderator on the relationship between rewards and knowledge sharing. Social exchange theory and structuration theory can account of development of reformation at organizational at different levels. Municipal government of Ternate is at a critical cross-road between "old culture" and "new culture", and the force of getting back to the previous point is always threatening. It can rejuvenate in new forms. Especially when the institution like municipal government of Ternate is challenged to maintain some elements of old culture in order to nurture its original identity. It explain several failures in the attempts of bureaucratic reformations in regional and national levels.

The reformation to good governance requires a full and continuous modification in case of driving-back force. The change should cover all stakeholders involved. Change attempt at governmental organization without the accompanying change of society or other stakeholders will go in vain. The people, parliamentary, businessman and others should act in the same tone until the change reaches its full entrenchment. Succession process can be an abrupt halting point where there still lack of an agreed-upon future direction and culture to live on. Continuity and discontinuity still characterizes Indonesia's changing policies which inhibit fast and significant progress required to win in the global era competition.

\section{CONCLUSION}

Municipal government of Ternate is Indonesia in miniature. It is at the brink of success in accomplishing knowledge-based reformation. However the road is a rather long to cross along which there are many points of driving back. The real entrenched change is 'cultural' where people to do the intended practice voluntarily. It finds support from structuration theory. The transient change is in transactional nature, and far much easier to go back the first place condition, as supported by social exchange theory.

\section{REFERENCES}

1. Allameh, S. M., Abedini, A., Pool, J. K., \& Kazemi, A. (2012). An analysis of factors affecting staffs knowledge sharing in the central library of the University of Isfahan using 
the extension of Theory of Reasoned Action International Journal of Human Resource Studies, Vol.2, (No.1) ,pp.158-174.

2. Al Murawwi, M. A., Behery, M., Papanastassiou, M., Ajmal, Mian. (2014). Examining the Relationship between Organizational Culture and Knowledge Management: The Moderation Effect of Organizational Divisions at an Abu Dhabi. Advanced Management Journal;Spring Vol. 79, (No. 2), pp. 48-59

3. Alrawi, K., Hamdan, Y., Wassan A.-T., and Ibrahim, M. 2013. Organizational culture and the creation of a dynamic environment for knowledge sharing.International Journal of Management and Innovation Vol. 5, Isu 1.

4. Amayah, A. T. (2013). Determinants of knowledge sharing in a public sector organization. Journal Of Knowledge Management, Vol. 17 (No. 3), pp. 454-471.

5. Ammar.D.N, Hayder. S. H. Norashikin. A. (2014).“Factors Influencing Knowledge Sharing in Organizations: A Literature Review", International Journal of Science and Research (IJSR), Vol 3, No. 9.

6. Bartol, K. and Locke, E. (2000). Incentives and motivation in Compensation in Organization. S. Rynes and B. Gerhart (eds). San Francisco: Jossey-Bass.

7. Blau, P. M. (1964). Exchange and Power in Social Life. Wiley: New York.

8. Bock, G.-W., Zmud, R. W., Young-Gul, K., \& Jae-Nam, L. (2005). Behavioral intention formation knowledge sharing: Examining roles of extrinsic motivators, socialpsychological forces, and organizational climate. MIS Quarterly, Vol. 29 (No. 1), pp. 87111.

9. Bock, G. and Kim, Y. (2002). Breaking the myths of rewards: an exploratory study of attitudes about knowledge sharing. Information Resources Management Journal, Vol. 15 No. 2, pp. 14-21.

10. Cabrera, E. and Cabrera, A. (2005) "Fostering Knowledge Sharing through People Management Practices" International Journal of Human Resource Management, Vol 16, pp 720-735.

11. Cavaliere, Vincenzo., and Lombardi, Sara. (2015). Exploring different cultural configurations: how do they affect subsidiaries' knowledge sharing behaviors?. Journal of Knowledge Management, Vol.19 Iss 2 pp.141-163.

12. Davenport, T.H. and Prusak, L. (1998). Working Knowledge: How Organizations Manage What They Know, Harvard Business School Press, Boston, MA.

13. DeLong, D. and Fahey, L. (2000) "Diagnosing Cultural Barriers to Knowledge Management", The Academy of Management Executive, Vol 14, No. 4, pp 113-127.

14. Demigha, S. (2015). "Knowledge Management and Intellectual Capital in an Enterprise Information System", ECkM, Eds. MaurizzioMassaro and Andrea Garlatti, pp 213-221.

15. Durmusoglu, S., Jacobs, M., Nayir, D. Z., Khilji, S., \& Wang, X. (2014). The quasi moderating role of organizational culture in the relationship between rewards and knowledge shared and gained. Journal Of Knowledge Management, Vol. 18 (No. 1), pp. 19-37.

16. Girard, John P.; Girard, JoAnn L. (2015)."Defining knowledge management: Toward an applied compendium" Online Journal of Applied Knowledge Management.3 (1): 14.

17. Hargadon, Andrew B (1998). Firms as knowledge brokers: Lessons in pursuing continuous innovation California Management Review; Vol.40, No.3, pg. 209.

18. Heydari, A. R., Armesh, Hamed., Behjatie, S.,and Manafi, M. (2011). Determinant of incentive factors in knowledge sharing. Interdisciplinary Journal of Contemporary Research in Business, Vol. 3 No. 1. Pp. 83-95

19. Kang, Y.J., Kim, S.E., \& Chang, G.W. (2008). The Impact of knowledge sharing on work performance: an empirical analysis of the public employees' perceptions in south korea. Intl Journal of Public Administration, 31, 1548-1568.

20. Kim, H. 2013. Transformational leadership, organizational clan culture, organizational affective commitment, and organizational citizenship behavior: A case of South Korea's Public Sector. Public Organiz Rev. 2014. 14: 397-417 
21. Kim, S., and Lee, H. (2006). The Impact of Organizational Context and Information Technology on Employee Knowledge Sharing Capabilities. Public Administration Review, 66(3), 370-385.

22. Kumar, N., \& Rose, R. C. (2012). The impact of knowledge sharing and Islamic work ethic on innovation capability. Cross Cultural Management, Vol. 19(No. 2), pp. 142-165.

23. Martı'n-Pe'rez, V'́ctor, Martı'n-Cruz, Natalia and Estrada-Vaquero, Isabel, (2012). Theinfluence of organizationaldesignonknowledge transfer. Journal of Knowledge management. Vol. 16, No. 3, pp. 418-434

24. Molm, L. D. (2001). "Theories of Social Exchange and Exchange Networks," in: The Handbook of Social Theory, Edited by George Ritzer and Barry Smart. Sage Press: London, pp.260-272.

25. Northcott, D., 2012. Using the balanced scorecard to manage performance in public sector organizations Issues and challenges. International Journal of Public Sector Management, 3. 2012, pp. 166-191

26. O'Dell, C. and Grayson, C. (1998) "If Only we Knew what we Know: Identification and Transfer of Internal Best Practices", California Management Review, Vol 40, No. 3, pp $154-174$.

27. O'Riordan, J., 2005. A Review of Knowledge Management in the Irish Civil Service. Institute of Public administration

28. Osterloh, M., and Frey, B. S.(2000). Motivation, Knowledge Transfer, and Organizational Forms.Organization Science (11:5), pp. 538-550

29. Rivera-Vazquez, J. C., Ortiz-Fournier, L. V., and Flores, F. R. (2009). "Overcoming cultural barriers for innovation and knowledge sharing", Journal of Knowledge Management, Vol 13, No. 5, pp 257-270

30. Schein, E. H. (2004). Organizational culture and leadership (3rd ed.). San Francisco:Jossey-Bass. Santa Monica, CA: RAND.

31. Shao, Zhen., Wang, Tienan., and Feng, Yuqiang. (2015). Impact of organizational culture and computer selfefficacy on knowledge sharing. Industrial Management \& Data Systems, Vol. 115 Iss 4 pp. $590-611$

32. Siddiquee, N.A., 2010. Managing for results: lessons from public management reform in Malaysia. International Journal of Public Sector Management, 23, pp.38-53.

33. Suppiah, V., \&Sandhu, M. S. (2011).Organizational culture's influence on tacit knowledge-sharing behaviour.Journal Of Knowledge Management, 3(15), pp. 462-477

34. Syed-lkhsan, S.O.S. Bin \& Rowland, F., 2004. Benchmarking knowledge management in a public organization in Malaysia.Benchmarking: An International Journal, 11(3), pp.238266.

35. Tohidinia, Z., \& Mosakhani, M. (2010). Knowledge sharing behaviour and its predictors. Industrial Management \& Data Systems, Vol. 110(No. 4), pp. 611-631.

36. Wickramasinghe, V., \& Widyaratne, R. (2012). Effects of interpersonal trust, team leader support, rewards, and knowledge sharing mechanisms on knowledge sharing in project teams. The journal of information and knowledge management systems, Vol. 42( No. 2), pp. 214-236

37. Wilson.Q.J.1989 Bureaucracy: What Government Agencies Do andWhy they Do It. New York: Basic Books. xiv, 433 .

38. Hamka, Burhanuddin, Idris, M., Fattah, S. Kualitas Pelayanan Publik: Implikasi Reorganisasi Kelembagaan Pemerintah Kabupaten / Kota

39. Witherspoon, C. L., Bergner, J., Cockrell, C., \& Stone, D. N. (2013). Antecedents of organizational knowledge sharing: a meta-analysis and critique. Journal of Knowledge Management, Vol 17 (No. 2), pp. 250-277

40. Wu, Y., \& Zhu, W. (2012). An integrated theoretical model for determinants of knowledge sharing behaviours. Kybernetes, Vol. 41 (No. 10), pp. 1462-1482. 